\title{
A Range Extension of the Karnataka Bronzeback, Dendrelaphis chairecacos (Boie 1827), from the Northern Western Ghats, India
}

\author{
P. Karthik ${ }^{1}$ and S.K. Dutta ${ }^{2}$
}

${ }^{1}$ Salim Ali Centre for Ornithology \& Natural History, Anaikatti, Coimbatore-641305, Tamil Nadu, India (karthikwildlifebiology@gmail.com) ${ }^{2}$ Nature Environment and Wildlife Society (NEWS), Nature House, Gaudasahi, Angul-759132, Odisha, India

$\mathrm{T}$ he ahaetuliid genus Dendrelaphis contains 45 currently recognized species (Uetz et al. 2019), 11 of which occur in India (Aengals et al. 2018). The taxonomy of these species was unresolved until clarified by Van Rooijen and Vogel (2009) and Vogel and Van Rooijen (2011a, 2011b), the former resurrecting $D$. chairecacos from the synonymy of $D$. tristis.

Little is known about Dendrelaphis chairecacos, which is assessed on the IUCN Red List as Data Deficient (Deepak et al. 2019). During a herpetofaunal survey conducted between November 2016 and July 2017 in the Sahyadri Tiger Reserve (17 $\left.04^{\prime} 00^{\prime \prime}-17^{\circ} 19^{\prime} 54^{\prime \prime N}, 73^{\circ} 40^{\prime} 43^{\prime \prime}-73^{\circ} 53^{\prime} 09^{\prime \prime} E\right)$, northern Western Ghats, India, we encountered an adult female at about 1130 h on 26 February 2017 (Figs. 1 \& 2). We recorded environmental and morphometric data and released the snake at the site of capture.

We confirmed the identity of the species using information in Van Rooijen and Vogel (2009) and Chandramouli and Ganesh (2012). The snake was at a height of $-1.8 \mathrm{~m}$ in a tree in tropical deciduous forest habitat (Karthik et al.

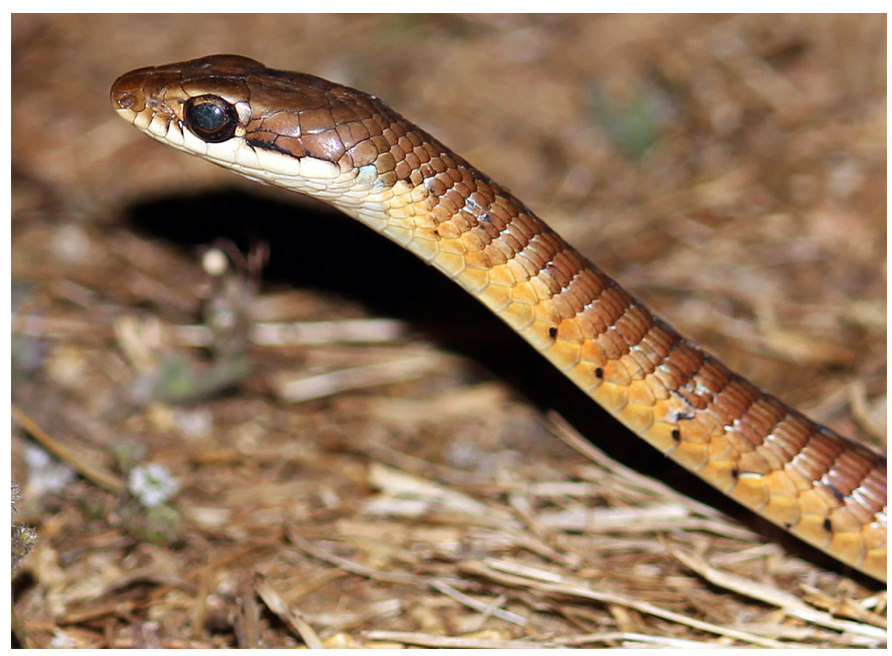

Fig. 1. An adult female Karnataka Bronzeback (Dendrelaphis chairecacos) from the Sahyadri Tiger Reserve, northern Western Ghats, India. Photograph by P. Karthik.

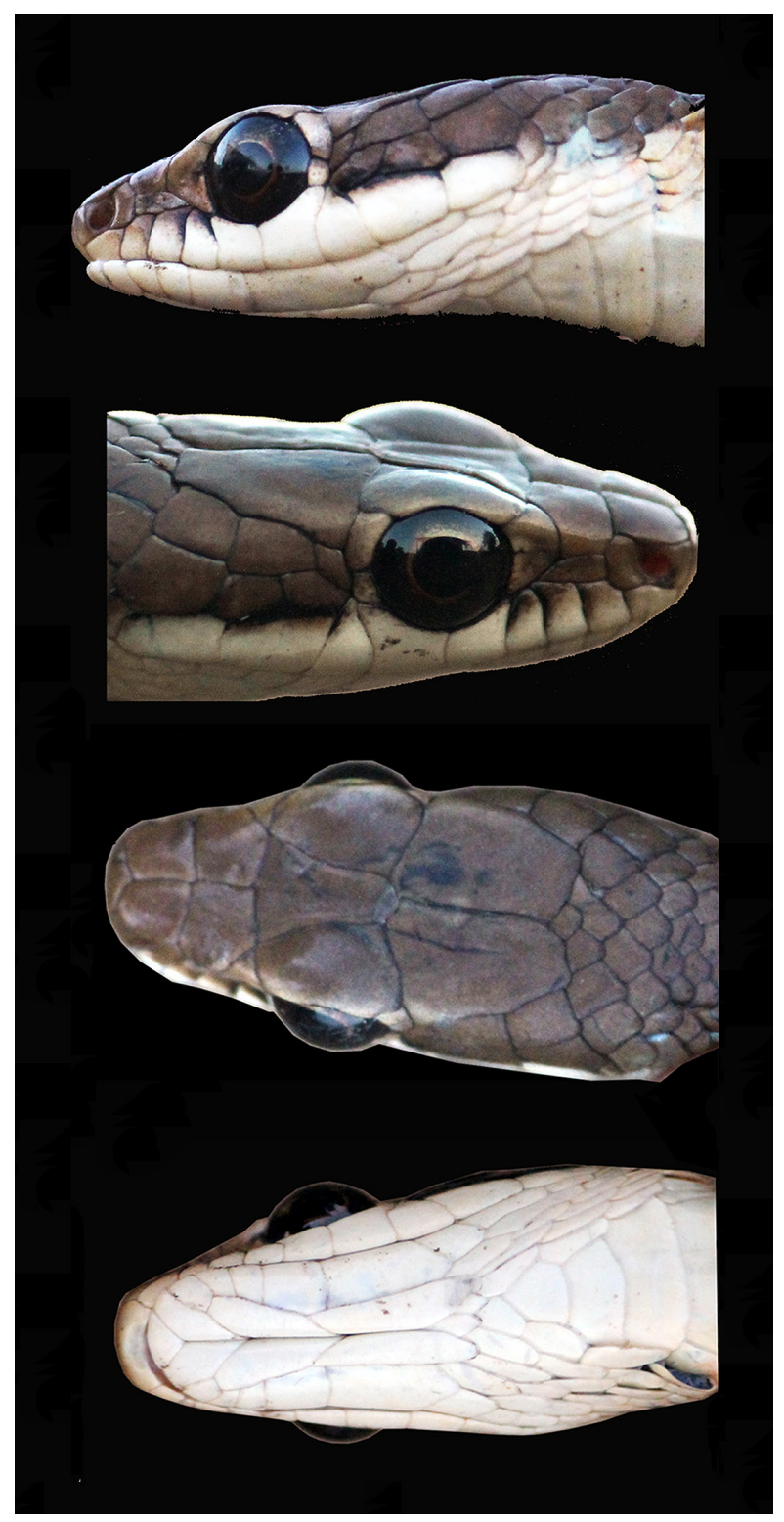

Fig. 2. Lateral, dorsal, and ventral views of the head of an adult female Karnataka Bronzeback (Dendrelaphis chairecacos) from the Sahyadri Tiger Reserve, northern Western Ghats, India. Photographs by P. Karthik. 


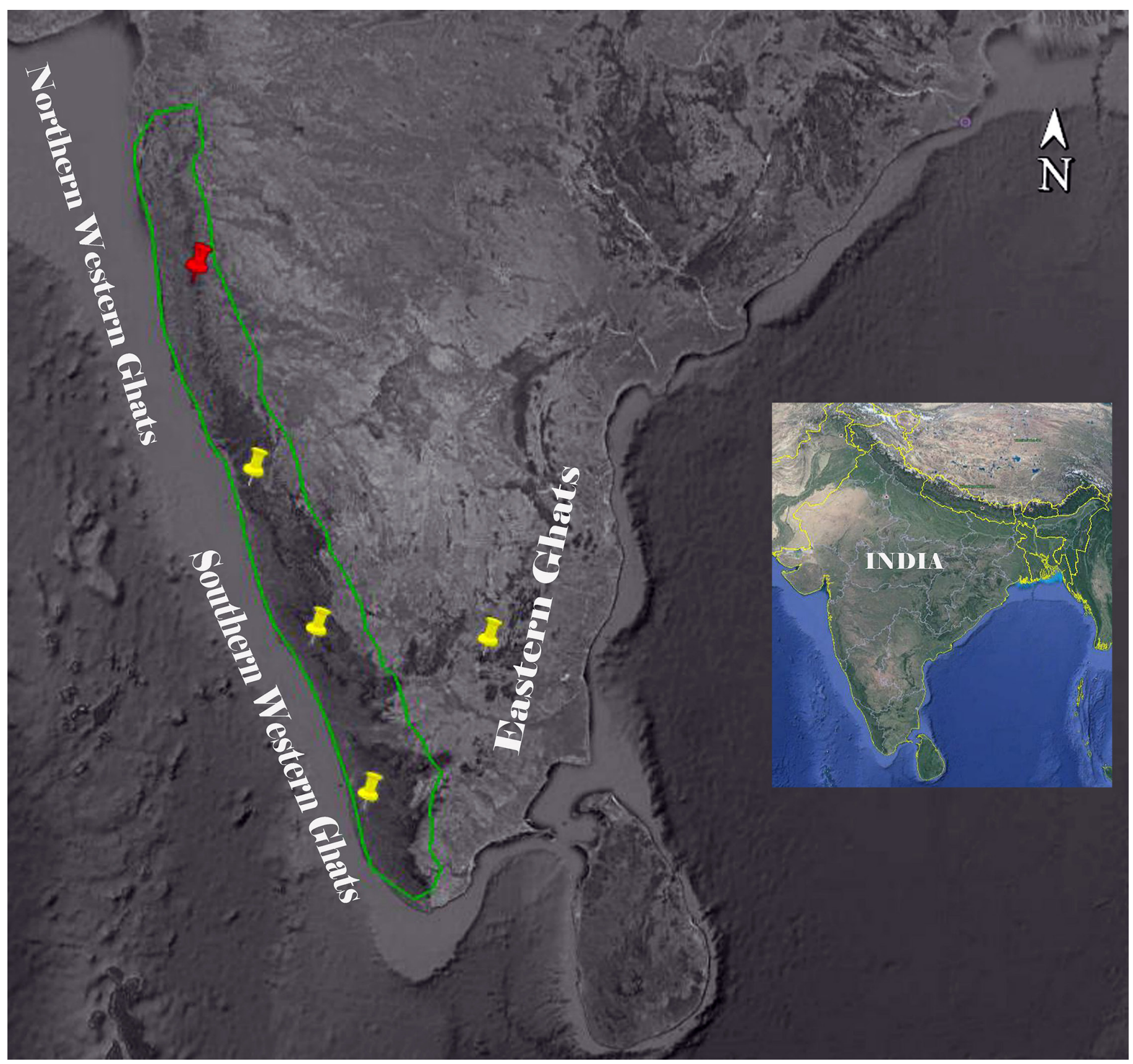

Fig. 3. Reported localities for the Karnataka Bronzeback (Dendrelaphis chairecacos) in peninsular India. The new locality reported herein is indicated by the red symbol; previously reported sites are marked by yellow symbols, including the only locality in the Eastern Ghats (Ganesh and Arumugam 2015). The Western Ghats are indicated by the green outline.

2019) at an elevation of $850 \mathrm{~m}$ asl. This location, $378 \mathrm{~km}$ north-northwest of the nearest previous location recorded by Chandramouli and Ganesh (2012), is only the fifth reported locality for the species and the first from the Northern Western Ghats (Fig. 2). Noteworthy is that this female had a snout-vent length of $830 \mathrm{~mm}$, exceeding the previous maxima of $480 \mathrm{~mm}$ reported by Van Rooijen and Vogel (2009) and $780 \mathrm{~mm}$ recorded by Chandramouli and Ganesh (2012). In addition, the elevation where this snake was encountered (850 $\mathrm{m}$ asl) dramatically exceeds the maximum elevation (400 $\mathrm{m}$ asl) listed by Deepak et al. (2019).

\section{Acknowledgements}

We thank Clement Ben (Chief Conservator of Forest) for granting permission and funding for this project; supervisors N.M. Ishwar, Nagarajan Baskaran, and S.R. Ganesh for encouragement and support; Orvill Jude Nazareth and other Sahyadri research mates from the Wildlife Institute of India for companionship in the field; and all Kolhapur Wildlife Division staff and biologists for support and accommodations.

\section{Literature Cited}

Aengals, R., V.M. Sathish Kumar, M.J. Palot, and S.R. Ganesh. 2018. A Checklist 
of Reptiles of India. Zoological Survey of India, Kolkata, India.

Chandramouli, S.R. and S.R. Ganesh. 2012. New records of Bronzeback Snakes (Serpentes: Colubridae: Dendrelaphis) from the Central Western Ghats of India and a revised key to South Indian Form. Sauria 34(2): 59-62.

Deepak, V., C. Srinivasulu, S.R. Ganesh, and B. Srinivasulu. 2013. Dendrelaphis chairecacos. The IUCN Red List of Threatened Species 2013: e.T194916A2368397. <http://dx.doi.org/10.2305/IUCN.UK.20131.RLTS. T194916A2368397.en>.

Ganesh, S.R. and M. Arumugam. 2015. Status and conservation of montane herpetofauna of Southern Eastern Ghats, India. Zoos' Print Journal 30(9): 18-22.

Karthik, P., O.J. Nazareth, N. Baskaran, and N.M. Ishwar. 2019. Notizen über den kryptischen Gecko Hemidactylus gleadowi Murray, 1884 aus dem Sahyadri Tiger Schutzgebiet, nördliche Western Ghats, Indien. Notes on the cryptic gecko Hemidactylus gleadowi Murray, 1884 from the Sahyadri Tiger Reserve, northern Western Ghats, India. Sauria 41(2): 70-76.

Uetz, P., P. Freed, and J. Hošek (eds.). 2019. The Reptile Database. <http://www. reptile-database.org>.

Van Rooijen, J. and G. Vogel. 2009. A multivariate investigation into the population systematics of Dendrelaphis tristis (Daudin, 1803) and Dendrelaphis schokari (Kuhl, 1820): revalidation of Dendrelaphis chairecacos Boie, 1827 (Serpentes: Colubridae). Herpetological Journal 19: 193-200.

Vogel, G. and J. van Rooijen. 2011a. A new species of Dendrelaphis (Serpentes: Colubridae) from the Western Ghats - India. Taprobanica 3: 77-85.

Vogel, G. and J. van Rooijen. 2011b. Contributions to a review of the Dendrelaphis pictus (Gmelin, 1789) Complex (Serpentes: Colubridae) - 3. The Indian forms, with description of a new species from the Western Ghats. Journal of Herpetology 14: 100-110. 